\title{
Hereditary breast and ovarian cancer (HBOC): review of its molecular characteristics, screening, treatment, and prognosis
}

\author{
Reiko Yoshida ${ }^{1} \mathbb{D}$
}

Received: 8 February 2020 / Accepted: 17 August 2020 / Published online: 29 August 2020

(c) The Author(s) 2020

\begin{abstract}
Breast cancer is a common cancer affecting a large number of patients. Notably, $5-10 \%$ of all breast cancer patients are genetically predisposed to cancers. Although the most common breast cancer susceptibility genes are BRCA1 and BRCA2, which are also associated with the risk of developing ovarian and pancreatic cancer, advances in next-generation sequencing (NGS) analysis technology enabled the discovery of several non-BRCA genes responsible for breast and ovarian cancers. Studies on hereditary breast and ovarian cancer (HBOC) involve not only determining the predisposition to developing cancer, but also considering the current treatment for breast cancer, prevention of next cancer, risk diagnosis, and adoption of protective measures for relatives. We present a comprehensive review of HBOC, which will be a useful resource in the clinical setting. Many hereditary tumors, including HBOC, are syndromes characterized by the development of different types of cancer in succession. Taking advantage of knowing predisposition of susceptibility to cancer, it is important to continue and update cancer management protocols, which includes the adoption of preventive measures, countermeasures, and treatments, to accurately assess and prevent the impact of cancer on the quality of life of the next generation of patients.
\end{abstract}

Keywords Hereditary breast and ovarian cancer $\cdot$ BRCA $\cdot B R C A 1 / 2$ mutations $\cdot$ HBOC

\section{Introduction}

Breast cancer is the most common cancer in women. According to the World Health Organization (WHO), the number of new cases of breast cancer in 2018 exceeded 2 million [1], accounting for $11.6 \%$ of all new cases of cancer in both men and women. The cumulative risk of developing breast cancer in the age range of $0-74$ years was 9.32 in North America, 2.81-4.17 in Asia, and the highest in Australia and New Zealand at 10.16. This shows that breast cancer is common cancer affecting a large number of patients. Besides, $5-10 \%$ of all breast cancer patients are genetically predisposed to cancers. Studies on hereditary breast and ovarian cancer (HBOC) involve not only determining the predisposition to developing cancer, but also considering the

Reiko Yoshida

reiyosh@med.showa-u.ac.jp

1 Showa University Advanced Cancer Translational Research Institute, 1-5-8 Hatanodai, Shinagawa-ku, Tokyo 142-8555, Japan current treatment for breast cancer, prevention of next cancer, risk diagnosis, and adoption of protective measures for relatives. This is a comprehensive review of HBOC, which will be a useful resource in the clinical setting.

\section{Hereditary breast and ovarian cancer (HBOC)}

Families with a history of multiple breast or ovarian cancers approximately account for $15 \%$ of all patients with breast cancer [2], and the disease is termed familial breast cancer (FBC). FBC includes people who are genetically predisposed to cancer. According to the National Cancer Institute, HBOC is defined as "An inherited disorder in which the risk of breast cancer (especially before the age of 50 years) and ovarian cancer is higher than normal." Most cases of HBOC syndrome are caused by certain mutations in BRCAI or $B R C A 2$. People with HBOC syndrome may also have an increased risk of developing other types of cancer, including melanoma, pancreatic and prostate cancers. This review will discuss the current knowledge regarding hereditary breast and ovarian cancer syndrome [3]. 


\section{Human BRCA1 and $B R C A 2$}

King et al. identified $B R C A l$ as the cause of hereditary breast cancer via linkage analysis using genetic polymorphism markers in 23,146 young individuals belonging to families affected by breast cancer. The existence of the gene was reported in 1990 [4]. In 1994, Miki et al. successfully cloned the gene and revealed its entire structure [5]. BRCAl is located at $17 \mathrm{q} 21$ near the centromere of the long arm of chromosome 17 and has 24 exons. The protein, composed of 1863 amino acids, consists of a central N-terminal RING finger domain, a C-terminal BRCT domain, and exons 11-13 (Fig. 1). The N-terminal RING finger domain of BRCA1 binds to BRCA1-associated RING domain protein 1 (BARD1), which is structurally similar to BRCA1 and forms a RING dimeric ubiquitin ligase (E3) [6]. Moreover, the C-terminal BRCT domain binds to phosphorylated proteins $[7,8]$, such as BRCA1A complex subunit (ABRAXAS) and BRCA1 interacting protein C-terminal helicase 1 (BRIP1), BTB and CNC homology 1 (BACH1), FANCJ, and C-terminal binding protein 1 (CtBP1) interacting protein [9]. The complexes containing these proteins are called BRCA1-A, -B, or -C complexes. BRCA2 binds (FNACN) to the coiled-coil domain located near the $\mathrm{C}$-terminal end encoded by exon 11 via PALB2 [10].

$B R C A 2$ (breast cancer susceptibility gene 2) was identified in 1995 by Wooster and colleagues, by analyzing $B R C A 1$ mutation-negative breast cancer families, including male patients with breast cancer [11]. BRCA2 is located on chromosome 13 (13q12-13), has 27 exons, and encodes a protein of 3418 amino acids. The $\mathrm{N}$-terminus of BRCA2 contains the transcription activation domain (TAD), while the middle part is encoded by exon 11 and contains eight conserved motifs called BRC repeats, which bind to RAD51 [12]. The DNA binding domain is located at the C-terminal end of BRCA2 and consists of a helical domain, three oligonucleotide-binding (OB) folds, and a tower domain (T). Double-stranded DNA (dsDNA) and single-stranded DNA (ssDNA) promote the binding of BRCA2 with [13]. The C-terminus of BRCA2 contains two NLSs (nuclear localization signals) and one TR2 (C-terminal RAD51 binding site).

\section{Functions of BRCA and its role in carcinogenesis}

DNA, which harbors genetic information, is constantly damaged by various internal and external factors, and is repaired via DNA single-strand break (ssDNA) repair, double-strand break (dsDNA) repair, and base mismatch repair (MMR). Depending on the type of damage, DNA is repaired via base excision repair (BER) and nucleotide repair (NER) [14]. BRCA1/2 are caretaker tumor-suppressor genes that repair DNA double-strand breaks via homologous recombination repair (HRR) to maintain genomic stability [15]. In addition to HRR, they also control centrosome dynamics, chromosome segregation, and cytokinesis, and stabilize the genome temporally and spatially in the cell cycle. In addition to the genomic instability caused by the disruption of these functions, a hormone-dependent carcinogenic environment [16] contributes to the basic flow via which breast cells are transformed into malignant phenotypes due to accelerated activation of survival signals. In addition to their role in
Fig. 1 BRCA protein. BRCA1 and BRCA2 are large hub proteins that bind other molecules involved in HR. It has been reported that the phenotype of breast and ovarian cancer differs depending on the location of the mutation (BCCR, OCCR [48])

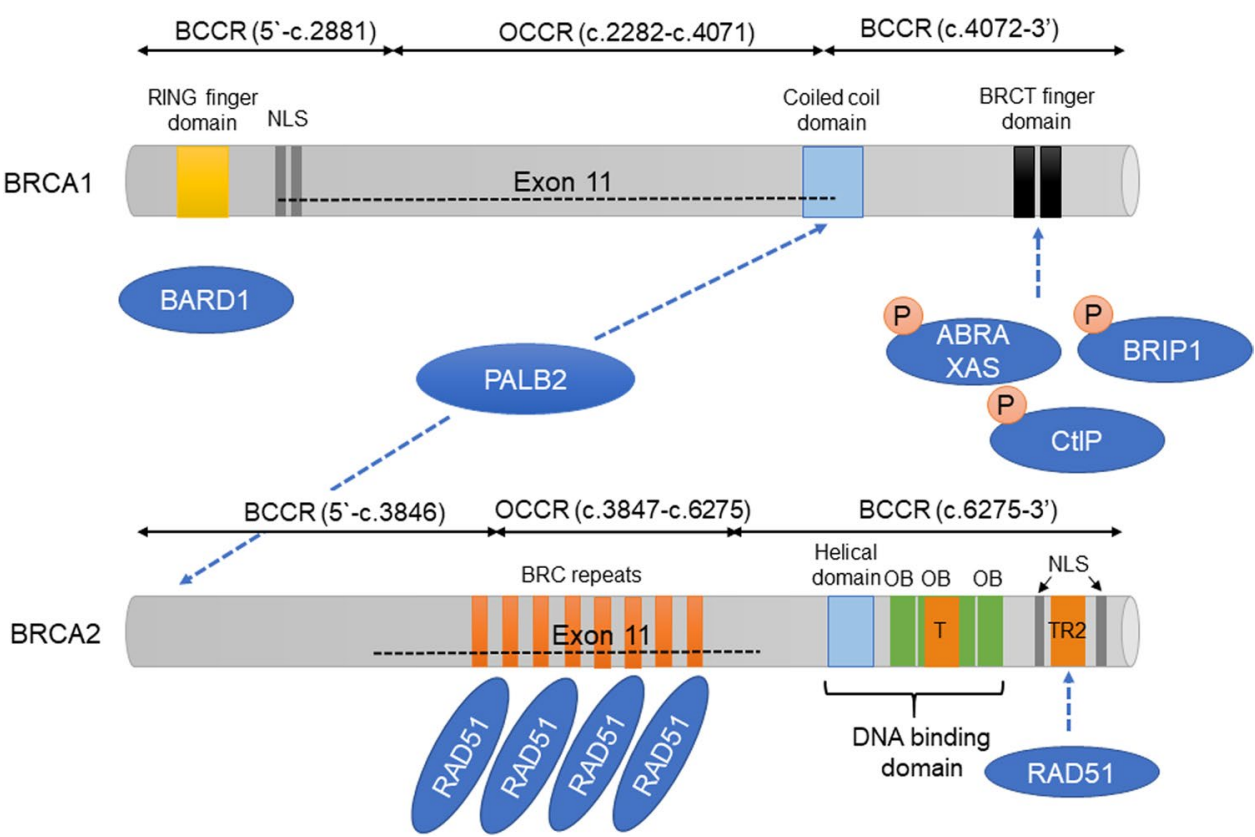


DNA damage repair, BRCA1 is involved in more functions than BRCA2, such as in healthy embryonic development and onset of breast and ovarian cancer [17], centrosome replication [18], regulation of spindle pole synthesis [19], heterochromatin-satellite RNA expression [20], mesenchymal metabolite synthesis [21], splicing [22], brain size [23], and transcriptional co-activation [24].

\section{Pathogenic variant (PV) of BRCA}

Currently, ClinVar, which is a freely available, public archive of human genetic variants and interpretations of their significance to disease, has registered more than 2,900 variants of $B R C A 1$ and more than 3,400 variants of $B R C A 2$ as pathogenic germline mutations [25]. The $80 \%$ of pathogenic or suspected pathogenic variants generate immature stop codons, truncate the encoded protein, and reduce their expression via nonsense-mediated mRNA decay (NMD). A truncating variant [26] with missense mutations accounts for $10 \%$ of these mutations. Pathological missense mutations tend to be confined to the RING and C-terminal tandem BRCT domains of $B R C A 1$, or the region spanning the OB-fold and helical domains of $B R C A 2$ [27]. Approximately $10 \%$ of the copy number abnormalities detected using deletion/duplication analysis varies among populations [28-31]

Genetic alterations are also observed at a high frequency in groups that are or were geographically or culturally isolated, in which one or more of the ancestors harbored the altered gene. This is often called the founder effect or founder variant [3]. Founder mutations of BRCA1/2 have been widely reported in different regions and ethnic groups. However, genetic testing for $B R C A 1 / 2$ should include uniform sequence analysis along with deletion/duplication analysis, except for in Ashkenazi Jews. Ashkenazi Jews can undergo targeted analysis of three BRCA1 and BRCA2 pathogenic founder mutations; 98-99\% of the PVs identified in Ashkenazi Jews are c.68_69delAG and c.5266dupC for BRCA1, and c.5946delT for BRCA2 [32-34]. If any PV cannot be identified using target analysis, sequence analysis, and deletion/duplication analysis, multiple gene panel analysis should be performed. Recently, many founder mutations have been reported in Asia (Tables 1, 2).

\section{Prevalence of $B R C A$ mutations}

$B R C A 1 / 2$ is the most frequent cause of high penetrance among HBOCs and affects all ethnic groups and races. The frequency of $B R C A 1 / 2$ pathogenic variants in the general population, excluding Ashkenazi Jews, has been estimated to be one in 400-500 [46, 47]. The mutation frequency of the first three variants of Ashkenazi Jews: c.68_69delAG of $B R C A 1$, c.5266dupC, and c.5946delT of BRCA2 is 1 in 40 [48]. Many recent reports have determined the frequency of $B R C A 1 / 2$ mutation retention in patients with breast and ovarian cancers without selection bias, without considering family history, age of onset, and cancer subtype. Among all patients with breast cancer without selection bias, the BRCA1/2 mutation retention rate was $4.2-6.1 \%$ (BRCA1: 1.45-3.7\%, BRCA2: 2.4-3.5\%) [48-52]. Among patients with ovarian cancer, the retention rate of $B R C A 1 / 2$ mutation was 8.3-14.7\% (BRCA1: 3.4-9.9\%, BRCA2: 4.7-5.3\%) [53-56].

\section{Risk assessment for patients with BRCA mutations}

As a standard for BRCAl/2 testing, clinical judgment is often made based on medical and family history. A representative example is the National Comprehensive Cancer Network Clinical Practice Guidelines in Oncology (NCCN Guidelines) [57]. To date, the NCCN guidelines have recommended a two-stage risk assessment, 1st step: further genetic risk evaluation, and 2 nd step: testing criteria, based on clinical findings of breast and ovarian cancer, as a comprehensive approach to genetic testing in subjects suspected of harboring BRCA1/2 mutations. However, with the recent advent of PARP inhibitors, which are expected to be effective against HRR-deficient cancer, and the popularity of genetic testing that detects HBOCs other than those with BRCA1/2 mutations, the current status of clinical practice, the 2020 version 1 called the "Approach To Cancer History" for all patients, has been revised to include recommendations for a more comprehensive approach for subjects who request genetic testing for HBOC-related genes (Fig. 2).

Many models have been developed to genetically and statistically predict $B R C A 1 / 2$ mutation retention based on past and family histories [58-61]. Although the quantified thresholds derived from these models may not be sufficient to determine whether BRCA1 or BRCA2 has a high probability of incorporating pathogenic variants, we cannot judge the validity of genetic testing. However, these models should be used as reference data for predicting BRCA mutation carriers.

\section{$B R C A 1$ and $B R C A 2$ are high-risk genes for breast and ovarian cancers}

Studies have shown that patients with breast and ovarian cancer, including fallopian tube and primary peritoneal cancer have high risk for harboring BRCA1/2 mutations. In addition, the risk of developing prostate cancer, pancreatic cancer, and malignant melanoma increases in the presence of these mutations. Estimates of malignant tumor risk vary with the reporting cohort and the method of risk evaluation.

Results from 24 studies showed that up to 70 years of age, the risk of women developing $B R C A l$ mutation is $46-87 \%$, while that for $B R C A 2$ mutation is $38-84 \%$. The 
Table 1 Reports of founder mutation (Caucasian)

\begin{tabular}{|c|c|c|c|c|}
\hline Population & $B R C A 1$ & $B R C A 2$ & Results & References \\
\hline Ashkenazi Jews & $\begin{array}{l}\text { c.68_69delAG } \\
\text { c.5266dupC }\end{array}$ & c.5946delT & $98-99 \%$ of $B R C A 1 / 2$ mutations & {$[35,36]$} \\
\hline Iceland & & c.767delG & Vast majority of $B R C A 1 / 2$ & \\
\hline Russia & c.5263insC & & $94 \%$ of $B R C A 1$ mutation & \\
\hline Poland & $\begin{array}{l}\text { c. } 5263 \text { insC } \\
\text { c. } 181 \mathrm{~T}>\mathrm{G} \\
\text { c. } 4034 \mathrm{delA}\end{array}$ & & $80 \%$ of $B R C A 1 / 2$ mutations, $91 \%$ of $B R C A 1$ mutations & \\
\hline Germany & $\begin{array}{l}\text { c.5263insC } \\
\text { c.181T }>\text { G } \\
\text { Exon17 del }\end{array}$ & & $38 \%$ of $B R C A 1$ mutations & \\
\hline Hungary & $\begin{array}{l}\text { c. } 5263 \text { insC } \\
\text { c. } 181 \mathrm{~T}>\mathrm{G} \\
\text { c.68_69delAG }\end{array}$ & $\begin{array}{l}\text { c.9098insA } \\
\text { c.5946delT }\end{array}$ & $80 \%$ of $B R C A 1$ mutations, $48 \%$ of $B R C A 2$ mutations & \\
\hline Norway & $\begin{array}{l}\text { c.1556delA } \\
\text { c.1016insA } \\
\text { c.697delGT } \\
\text { c.3228delAG }\end{array}$ & & $\begin{array}{l}68 \% \text { of } B R C A 1 \text { mutations c. } 1556 \mathrm{delA} \text { and c.1016insA } 3 \% \text { of } \\
\text { ovarian cancer }\end{array}$ & \\
\hline Finland & $\begin{array}{l}\text { c. } 4096+3 \mathrm{~A}>\mathrm{G} \\
\text { c. } 4327 \mathrm{C}>\mathrm{T}\end{array}$ & $\begin{array}{l}\text { c. } 9117+1 \mathrm{G}>\mathrm{A} \\
\text { c. } 7480 \mathrm{C}>\mathrm{T} \\
\text { c. } 8327 \mathrm{~T}>\mathrm{G} \\
\text { c. } 3376 \mathrm{delTT}\end{array}$ & $84 \%$ of $B R C A 1 / 2$ mutations & \\
\hline Sweden & c.3052insC & c.6373delA & $70 \%$ of $B R C A 1 / 2$ mutations in West Sweden & \\
\hline Denmark & $\begin{array}{l}\text { c. } 2475 \mathrm{delC} \\
\text { c. } 3319 \mathrm{G}>\mathrm{T} \\
\text { c. } 5263 \mathrm{insC} \\
\text { c. } 3709 \mathrm{delT}\end{array}$ & $\begin{array}{l}\text { c. } 1310 \mathrm{del} 4 \\
\text { c.5946del4 }\end{array}$ & $35 \%$ of $B R C A 1 / 2$ mutations & \\
\hline French & $\begin{array}{l}\text { c.3481del11 } \\
\text { G1570X }\end{array}$ & & $52 \%$ of $B R C A 1 / 2$ mutations & \\
\hline
\end{tabular}

Table 2 Reports of founder mutation (Asian)

\begin{tabular}{|c|c|c|c|c|}
\hline Population & Mutation in $B R C A 1$ & Mutation in $B R C A 2$ & Proportion of $B R C A 1 / 2$ & References \\
\hline Southern Chinese & c.981_982delAT & $\begin{array}{l}\text { c. } 3109 \mathrm{C}>\mathrm{T} \\
\text { c.7436_7805del370 } \\
\text { c.9097_9098insA }\end{array}$ & $23 \%$ of $B R C A 1 / 2$ & {$[37]$} \\
\hline Mainland Chinese & c.981_982delAT & $\begin{array}{l}\text { c.3195_3198delTAAT } \\
\text { c.5576_5579delTA }\end{array}$ & $5 \%$ of $B R C A 1 / 2$ & {$[38]$} \\
\hline Japanese & c. $188 \mathrm{~T}>\mathrm{A}$ & & c. $188 \mathrm{~T}>\mathrm{A}$ variant $16 \%$ of $B R C A 1 / 2$ & {$[39,40]$} \\
\hline Koreans & $\begin{array}{l}\text { c. } 3627 \text { insA } \\
\text { c.922_924delAGCinsT }\end{array}$ & c. $7480 \mathrm{C}>\mathrm{T}$ & $\begin{array}{l}10 \% \text { of } B R C A 1 / 2 \\
10 \% \text { of } B R C A 1 / 2 \\
10 \% \text { of } B R C A 1 / 2\end{array}$ & $\begin{array}{l}{[41,42]} \\
{[42]}\end{array}$ \\
\hline Malaysians & c.2727insA & & $6 \%$ of $B R C A 1$ & [43] \\
\hline Filipinos & & $\begin{array}{l}\text { c. } 4037 \mathrm{delCT} \\
\text { c. } 4631 \mathrm{delA}\end{array}$ & $\begin{array}{l}13 \% \text { of } B R C A 1 / 2 \\
26 \% \text { of } B R C A 1 / 2\end{array}$ & [44] \\
\hline & c. $5335 \mathrm{delC}$ & & $13 \%$ of $B R C A 1 / 2$ & {$[45]$} \\
\hline
\end{tabular}


Fig. 2 Risk assessment for HBOC. HBOC risk assessment is recommended to be comprehensive for all cancer patients instead of the traditional individual approach

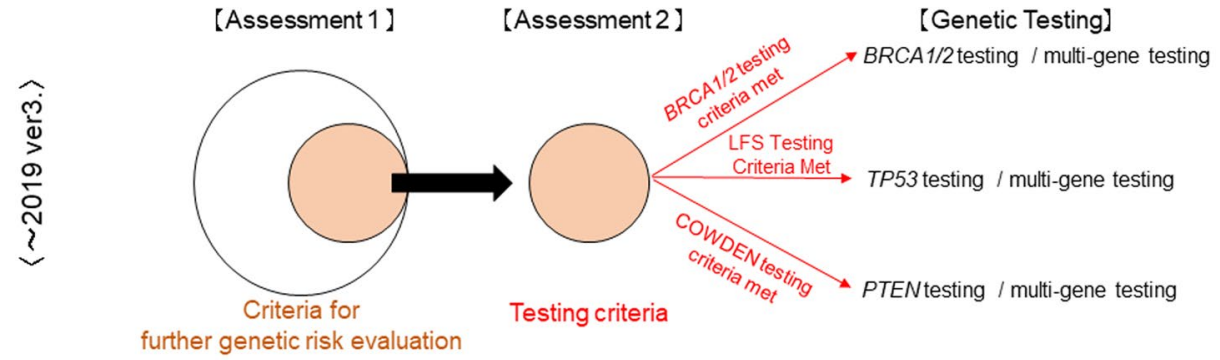

[Approach To Cancer History For All Patients ]

【Genetic Testing】

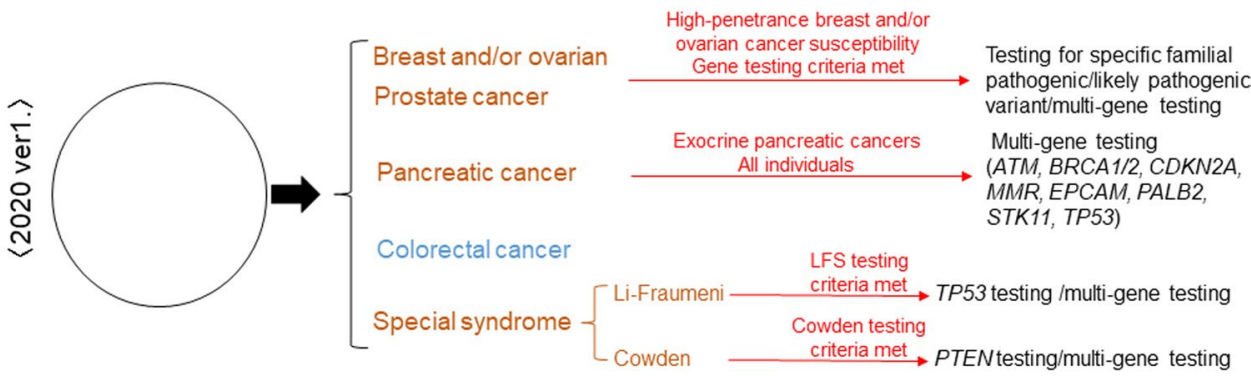

(\%) 100

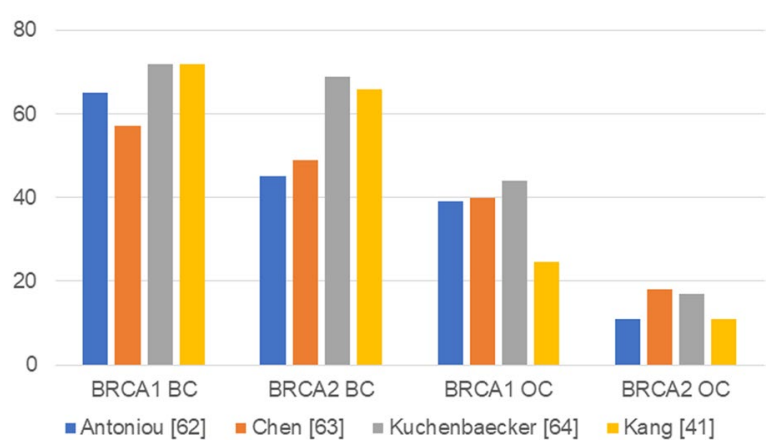

Fig. 3 Cumulative risk of breast and ovarian cancer (women). Four studies reported the prevalence of breast and ovarian cancers in women up to the age of $70[41,62,63]$ and 80 [64] carrying $B R C A$ mutations. Two reports, [62] and [63] are meta-analysis studies, covering 22 and 10 studies, respectively, and [63] is the most extensive prospective study with 3986 BRCA1 and 5066 BRCA2 cancerfree mutation carriers; [41] is the Asian cohort study, involving 108 Korean $B R C A 1 / 2$ mutation carriers. Data from a large number of prospective studies are desirable for calculating the risk of developing a rare genetic disorder, as family history is prone to bias

risk of developing ovarian cancer with a $B R C A 1$ mutation is $39-63 \%$, while it is $16.5-27 \%$ for $B R C A 2$; the risk for developing male breast cancer due to BRCAl mutation is $1.2 \%$, while it is $8.9 \%$ for $B R C A 2$; the risk of developing prostate cancer in men up to 65 years of age due to BRCAl mutation is $8.6 \%$, while it is $15 \%$ for $B R C A 2$; the risk of developing pancreatic cancer due to $B R C A 1$ mutation is $1-3 \%$, while it is $2-7 \%$ for $B R C A 2$ mutation [32]. Two retrospective metaanalysis studies [62, 63] and a large prospective study [64] are shown in Fig. 3. However, since BRCA1/2 mutations are rare in the general population, most retrospective penetrance estimates have been derived from family-based studies, which are prone to bias, if analyses are not correctly adjusted for the ascertainment process or in case of inaccurate family history. In addition, despite the retrospective nature of our cohort study, data for the Asian population, including a report from Korea, are valuable to clinicians [41]

\section{$B R C A$ contralateral breast cancer $(C B C)$ risk}

BRCA1/2 mutation carriers also have a significantly increased risk of developing CBC $[65,66]$. The 5-, 10-, and 15-year cumulative CBC risk of 810 female $B R C A 1 / 2$ breast cancer patients is $13.7 \%, 23.8 \%$, and $36.1 \%$ for $B R C A l$ and $12.0 \%, 18.7 \%$, and $28.5 \%$ for $B R C A 2$, respectively [67]. The overall risk of $\mathrm{CBC}$ in women with $B R C A 1 / 2$ mutations was $2.2 \%$, and the annual risk for breast cancer in patients aged 40 years and younger increased to $2.8 \%$. A prospective cohort study of $1305 B R C A 1$ positive and 908 BRCA2 positive breast cancer patients found that the risk of $\mathrm{CBC}$ 20 years after initial breast cancer was $40 \%$ for $B R C A l$ and $26 \%$ for $B R C A 2$. The younger the age of onset of the first breast cancer, the higher the risk of CBC [64].

\section{BRCA genotypes and phenotypes}

The relationship between mutation sites and breast and ovarian cancer risks has been reported. In patients harboring both $B R C A 1$ and $B R C A 2$, multiple ovarian cancer regions (OCCR) have been identified within or adjacent to exon 11 [68]. PVs in OCCR increase the proportion of ovarian 
to breast cancer, unlike families with PV at other sites in both genes. Similarly, a large number of breast cancer-prone regions (BCCRs) have been observed for $B R C A 1 / 2$ and are associated with a relative increase in breast cancer risk and a relative decrease in ovarian cancer risk. A prospective cohort study of BRCA1/2 cancer-free mutation carriers [64] also reported that the relative risk of developing cancer varies with the location of the mutation (BCCR, OCCR). However, the reported hazard ratio for cancer development due to differences in the location of the mutations is almost two or less, and it is premature to use it for individual risk assessment and management. The clinical application should be considered in the future after an appropriate experimental validation.

\section{Radiation risks of patients with $B R C A$ mutations}

Radiation causes DNA damage, either directly by ionization or indirectly by radicalizing molecules, such as water, causing DNA damage, such as DNA base changes, crosslinking of DNA and proteins, and DNA single- or doublestrand breaks. As these changes are known to cause cancer, radiation-induced carcinogenesis may occur in $B R C A$ mutation carriers, as $B R C A 1 / 2$ is involved in double-strand break repair. Several prospective and retrospective studies have investigated the effect of medical radiation exposure on carriers of BRCA mutations. A retrospective cohort study, GENE-RAD-RISK, reported a relationship between medical radiation exposure, including mammography and breast cancer in 1,993 women with unaffected BRCA1/2 mutations. Patients who received mammography before age 30 had an increased risk of breast cancer compared to those who were not exposed (hazard ratio $=1.43$ ) [69]. However, questionnaire surveys suggest that this study may have recall bias. Subsequently, a prospective study investigating the effects of mammography on 2346 women with $B R C A$ mutations, considered the 5-year cumulative breast cancer incidence and reported no significant difference in the risk of developing breast cancer relative to the mammography history and mammography initial age [70]. Although the relationship between carriers of BRCA mutations and the development of radiation-induced breast cancer is not yet clear, after considering the age of breast cancer occurrence and the benefits of surveillance using mammography, many guidelines recommend MMG screening from the age of 25.

\section{Characteristics of $B R C A$-related breast and ovarian cancer}

\section{Pathology of breast and ovarian cancer}

The Western Consortium of Investigators of Modifiers of BRCA1/2: the CIMBA reports on the pathological findings of $B R C A 1 / 2$ breast cancer as follows [71, 72]: BRCA1related breast cancer has the following features: (1) histopathological image of medullary carcinoma, which develops in a globular manner in peripheral tissues, (2) high histological nuclear grade, (3) a high proportion of negative for the expression of both estrogen and progesterone receptors and HER2 overexpression. The histology of the BRCA2-mutated breast cancer tissue is almost similar to those without $B R C A$ mutations, and the histological nuclear grade is generally high (Table 3 ). In addition, high-grade serous adenocarcinoma has been reported as a pathological feature of $B R C A 1 / 2$ ovarian cancer [71, 73]. Both $B R C A 1 / 2$-related breast and ovarian cancers are typically highly aggressive (Table 3 ).

\section{Prognosis of $B R C A$ cancer}

The prognosis of breast cancer in $B R C A 1 / 2$ mutation carriers has been reported extensively, and the results of largescale cohorts and meta-analyses in this regard are as follows. Pooled analysis of 16 studies, including 1325 with BRCA1/2 mutation and 8855 with no mutation regarding the overall survival of patients with breast cancer harboring $B R C A 1 / 2$ mutations, revealed a correlation between the presence of $B R C A 1 / 2$ mutation and overall survival. No correlation was observed in terms of hazard ratio (hazard ratio $=1.06, p=0.61$ ) [74]. In addition, the results of a 127 multi-center prospective cohort study in the UK involving 2733 women with breast cancer under the age of 40 years, including $388 B R C A 1 / 2$ mutation carriers, showed no relationship between the presence of $B R C A 1 / 2$ mutations, and 2-, 5- and 10-year overall survival. In a cohort consisting of 588 patients with triple-negative breast cancer, the $B R C A 1 / 2$ mutation carriers showed significantly higher 2-year overall survival rates (hazard ratio $=0.59$, $p=0.047$ ); however, no difference at 5- and 10-years was reported [75]. This slight early survival advantage might be linked to greater sensitivity of BRCA-mutant breast cancers to chemotherapy. A meta-analysis of 33 studies of patients with ovarian cancer showed that overall survival (hazard ratio $=0.75, p<0.001$ ) and progression-free survival (hazard ratio $=0.80$ ) in the $B R C A 1 / 2$ mutation cohort $(p=0.039)$ were significantly extended compared to that of patients with no $B R C A$ mutation. BRCAl mutation alone 
Table 3 Pathological features of $B R C A 1 / 2$-related breast and ovarian cancer

\begin{tabular}{|c|c|c|c|c|}
\hline & BRCAl & & $B R C A 2$ & \\
\hline Breast cancer & Mavaddat [71] & Kuchenbaecker [72] & Mavaddat [71] & Kuchenbaecker [72] \\
\hline \multicolumn{5}{|l|}{ Histology } \\
\hline Invasive ductal & $80 \%$ & $82 \%$ & $83 \%$ & $79 \%$ \\
\hline Invasive lobular & $2.20 \%$ & $2 \%$ & $8.40 \%$ & $8 \%$ \\
\hline Medullary & $9.40 \%$ & $6 \%$ & $2.20 \%$ & $2 \%$ \\
\hline Other & $8.60 \%$ & $10 \%$ & $6.40 \%$ & $11 \%$ \\
\hline \multicolumn{5}{|l|}{ Grade } \\
\hline Grade 1 & $3 \%$ & $3 \%$ & $7 \%$ & $7 \%$ \\
\hline Grade 2 & $20 \%$ & $18 \%$ & $43 \%$ & $42 \%$ \\
\hline Grade 3 & $77 \%$ & $79 \%$ & $50 \%$ & $51 \%$ \\
\hline \multicolumn{5}{|c|}{ ER, PgR, HER2, TN } \\
\hline ER-positive & $22 \%$ & $24 \%$ & $77 \%$ & $77 \%$ \\
\hline PgR-positive & $21 \%$ & $21 \%$ & $64 \%$ & $65 \%$ \\
\hline HER2-positive & $10 \%$ & $9 \%$ & $13 \%$ & $13 \%$ \\
\hline Non-TN & $31 \%$ & $31 \%$ & $84 \%$ & $85 \%$ \\
\hline Ovarian cancer & Mavaddat [71] & McLaughlin [73] & Mavaddat [71] & McLaughlin [73] \\
\hline \multicolumn{5}{|l|}{ Histology } \\
\hline Serous & $66 \%$ & $73.60 \%$ & $70 \%$ & $73 \%$ \\
\hline Mucinous & $1 \%$ & $0 \%$ & $1 \%$ & $0 \%$ \\
\hline Endometrioid & $12 \%$ & $14.70 \%$ & $12 \%$ & $8.90 \%$ \\
\hline Clear cell & $1 \%$ & $0.80 \%$ & $3 \%$ & $2.30 \%$ \\
\hline Other & $20 \%$ & $10.90 \%$ & $13 \%$ & $15.70 \%$ \\
\hline \multicolumn{5}{|l|}{ Grade } \\
\hline Grade 1 & $3 \%$ & $1.60 \%$ & $6 \%$ & $0 \%$ \\
\hline Grade 2 & $20 \%$ & $15.50 \%$ & $21 \%$ & $21.40 \%$ \\
\hline Grade 3 & $77 \%$ & $56.60 \%$ & $73 \%$ & $52.80 \%$ \\
\hline Unknown & - & $26 \%$ & & $25.80 \%$ \\
\hline
\end{tabular}

Mavaddat: (2011 3,797 BRCA1 mutationcarriers and 2,392 BRCA2 mutation carriers diagnosed with invasive breast cancer., 838 BRCA1 mutation carriers and 281 BRCA2 mutation carriers who had been diagnosed with ovarian cancer Kuchenbaecker(2014 Breast tumor characteristics of 7,797 affected BRCA1 mutation carriers and 4,330 affected BRCA2 mutation carriers) McLaughlin(2013: 129 BRCA1 mutation carriers and 89 BRCA2 mutation cariers diagnosed with ovarian cancer) improved overall survival (hazard ratio $=0.75$ ), although no significant difference in progression-free survival was observed; besides, no significant difference in overall or progression-free survival was observed for patients carrying $B R C A 2$ mutation alone. In a large study involving 626 patients with ovarian cancer without selection bias, patients with 218 BRCA1/2 mutations had better 3-year short-term survival than the mutation-free group. However, reports show that this effect on survival is shortterm and that long-term survival beyond 10 years does not improve [73].

\section{Locus-specific loss of heterozygosity (LOH)}

A few reports suggested a correlation between prognosis and the presence or absence of $\mathrm{LOH}$ in cancers of germline $B R C A 1 / 2$ mutation carriers. Of 160 cancers with $B R C A 1 / 2$ mutations, $\mathrm{LOH}$ was detected in $90 \%$ cases of $B R C A l$ positivity and $54 \%$ cases of $B R C A 2$ positivity in breast cancer, and in $93 \%$ cases of $B R C A 1$ positivity and $84 \%$ cases of $B R C A 2$ positivity in ovarian cancer. In patients with breast cancer, the overall survival rate was better in the BRCA1/2positive group than in the negative group; however, overall survival did not differ significantly with the presence or absence of $\mathrm{LOH}$ in cancer. The overall survival rate of patients with $B R C A$-positive cancers was significantly better, with that of $B R C A 1 / 2$-positive groups without $\mathrm{LOH}$ being as low as that of $B R C A$-negative groups [76]. The presence or absence of $\mathrm{LOH}$ in tumors should be considered as a new stratification factor when predicting the effects of drugs, such as PARP inhibitors. 


\section{Non-BRCA genes related to $\mathrm{HBOC}$}

\section{HBOC-related genes and multi-gene panel (MGP) testing}

A review of the causative genes of $\mathrm{FBC}$ showed that only $25 \%$ of cases retained the $B R C A 1 / 2$ mutations, whereas four high-susceptibility genes, other than $B R C A 1 / 2$, namely $C D H 1, P T E N, S T K 11$, and TP53, were detected in $5 \%$ of patients. Another $5 \%$ of cases reported medium penetrance genes (RR: 2-4), and 14\% low penetrance genes $(\mathrm{RR}<2)$, whereas the causative gene was unknown in $51 \%$ cases [77]. Nearly all known HBOC susceptibility genes encode tumor suppressors that participate in genome stability pathways, in particular HRR, and to some extent mismatch repair (MMR), as well as interstrand DNA cross-link repair via the Fanconi anemia pathway [78]. Advances in next-generation sequencing (NGS) analysis technology enabled cost-effective and increasingly efficient genetic testing. Hence, from the era of investigating single genes one at a time, we have now advanced to MGP testing, which allows to assess many candidate genes simultaneously. Various types of MGP testing for HBOC are currently available. The results of gene mutation detection rates using MGP testing in patients with over 7000 breast cancer without selection bias are shown in Fig. 4a (Momozawa et al. [64], Sun et al. [65], Buys et al. [79], Couch et al. [80], Theobald et al. [81]). References [79-81] report the results of a testing company mainly targeting Caucasians, and references [64, 65] report cohort studies focusing on Asians. In the Caucasian-centered cohort, $B R C A 1$ and $B R C A 2$ showed similar PV prevalence; however, in Asian cohorts, the prevalence of $B R C A 2$ tended to
Fig. 4 a Results of MGP testing for unselected patients with breast cancer (ATM, BRCA1, BRCA2, CHEK2, PALB2, $P T E N, T P 53)$. Genetic prevalence is suggested to differ by cohort background and ethnicity. b PV prevalence (all genes). BRCA2 mutation prevalence is still high in Asian cohorts, even as the number of genes examined increases

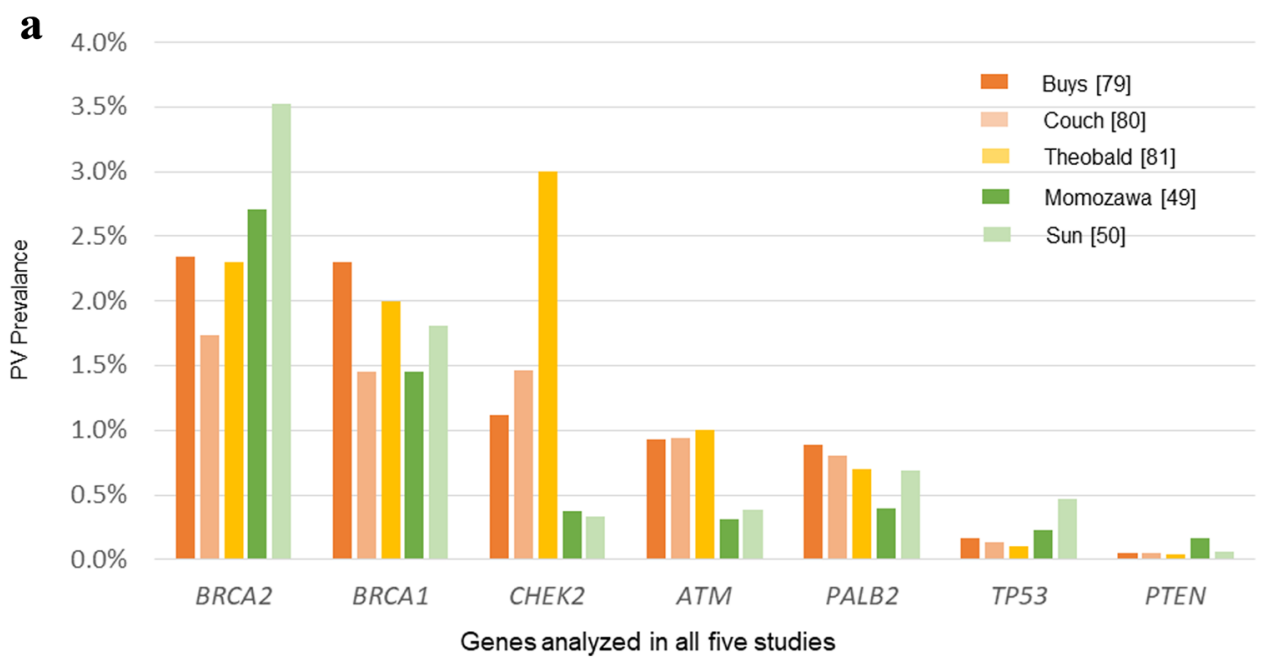

b 
be high, whereas that of CHEK2/ATM tended to be low. In addition, genes with PV were analyzed between the three of five studies, which analyzed genes using only one-panel testing in their cohort (Fig. 4b). BRCA2 mutation carriers showed high penetrance in Asian cohorts, even when more genes were considered. The following points should be noted when performing MGP testing. According to a review report summarizing the results of 23 MGP testing, the variant of uncertain significance (VUS) detection rate was as high as $0.6-88 \%$. It is necessary to pay attention to the economic and mental burden of carrying mutations for which medical management is unknown [82]. The utility of the MGP test is not only to detect a high prevalence of PV, but also to expand the possibility of finding genetic diseases that were not expected from information on family and individual medical histories, and to take new measures. Identification of pathogenic variants in genes associated with cancer can open new therapeutic avenues.

\section{Clinical features of high penetrance genes in breast cancer}

The clinicopathological findings regarding the high penetrance genes involved in breast cancer, including BRCA1/2, are shown in Table 4 [83-87]. The mean age at which cancer develops is lower in patients with TP53 and PTEN mutations than in those with $B R C A 1 / 2$ mutations, and therefore, it is necessary to pay attention to the age at which surveillance begins. Although large-scale evidence is still scarce for medium- to low-risk genes, limited studies on PALB2, $A T M, C H E K 2$, etc., are being reported in fast succession, and it is expected that the clinicopathological features and appropriate medical management will be further clarified in the future by accumulating data offered by MGP.

\section{Treatment for current breast cancer}

\section{Surgery}

It is generally recognized that breast-conserving surgery (BCT) is an alternative to mastectomy for early breast cancer. However, the relative contraindications for BCT with breast irradiation in the NCCN guidelines include "women with known or suspected genetic predisposition to breast cancer" [88]. The possible reasons include increased risk of ipsilateral breast recurrence or $\mathrm{CBC}$ in women with HR-related or radiosensitive germline mutations, such as Li-Fraumeni syndrome, complications of breast reconstruction after breast irradiation, and consideration of prophylactic bilateral mastectomy (BRRM). The risk of developing ipsilateral breast recurrence and CBC survival after BCT in BRCA1/2 mutation carriers has long been discussed. A recent review examined six retrospective studies on BCT toxicities in BRCA mutation carriers and non-carriers, six retrospective studies on $\mathrm{BCT}$ and mastectomy in BRCA mutation carriers, one review of 11 retrospective studies on BCT of IBTR, CBC, distant recurrence, and overall survival, and one metaanalysis report [89]. Although it is unclear whether the risk of long-term IBTR, including new primary IBTR, increases after BCT in BRCA mutation carriers and noncarriers, no significant differences in BCT toxicities,

Table 4 Clinicopathological features of high penetrance HBOC genes

\begin{tabular}{|c|c|c|c|c|c|}
\hline & $B R C A 1 B R C A 2$ & TP53 (Li-Fraumeni syndrome) & $\begin{array}{l}\text { PTEN (Cowden } \\
\text { syndrome) }\end{array}$ & $\begin{array}{l}\mathrm{CDHl} \text { (Hereditary } \\
\text { diffuse gastric cancer) }\end{array}$ & $\begin{array}{l}\text { STK11 (Peutz-Jeghers } \\
\text { syndrome) }\end{array}$ \\
\hline \multirow[t]{4}{*}{ Component tumor } & \multirow{4}{*}{$\begin{array}{l}\text { Breast, Ovary, Pros- } \\
\text { tate, Pancreatic }\end{array}$} & Adrenal Gland & Breast, Endometrioid & Gastric & Gastrointestinal \\
\hline & & Breast (premenopausal), brain & Colorectal & Breast & $\begin{array}{l}\text { Breast, Ovary, Endo- } \\
\text { metrioid }\end{array}$ \\
\hline & & Soft tissue/bone & Thyroid & Colorectal & \\
\hline & & Sarcoma & Renal & & \\
\hline \multirow[t]{2}{*}{$\begin{array}{l}\text { Breast cancer pen- } \\
\text { etrance (women) }\end{array}$} & $\begin{array}{l}\text { BRCA1: } 71 \%(\sim \\
\quad 80 \text { years })\end{array}$ & $54 \%$ ( 70 years $)$ & $67-85 \%$ & $39-52 \%$ & $45-50 \%$ \\
\hline & $\begin{array}{l}\text { BRCA2: } 69 \%(\sim \\
80 \text { years) }\end{array}$ & & & & \\
\hline \multirow{2}{*}{$\begin{array}{l}\text { Age of breast cancer } \\
\text { onset (average) }\end{array}$} & BRCA1: 44 years & 33 years & $38 \sim 46$ years & 53 year & Insufficient data \\
\hline & BRCA2: 48 years & & & & \\
\hline \multirow{2}{*}{$\begin{array}{l}\text { PV prevalence } 35,000 \\
\text { breast cancer cohort } \\
\text { [79] }\end{array}$} & BRCA1: $2.30 \%$ & $0.17 \% 4-8 \%$ of $B R C A$-negative breast cancers under & $<0.1 \%$ & $<0.1 \%$ & $<0.1 \%$ \\
\hline & BRCA2: $2.34 \%$ & 30 years of age are TP53 mutation-positive & & & \\
\hline \multirow[t]{2}{*}{$\begin{array}{l}\text { Pathological feature of } \\
\text { breast cancer }\end{array}$} & $\begin{array}{l}\text { BRCA1: TN, } 77 \% \text {; } \\
\quad \text { NG2 or } 3,97 \%\end{array}$ & $H E R 2+: 66 \%$ NG2 or $3: 86 \%$ & Insufficient data & $\begin{array}{c}\text { Invasive lobular } \\
\text { carcinoma }\end{array}$ & Insufficient data \\
\hline & $\begin{array}{l}\text { BRCA2: Luminal, } \\
77 \% \text {; NG2 or } 3 \text {, } \\
93 \%\end{array}$ & & & & \\
\hline References & {$[32,57,70]$} & {$[32,57,84,85]$} & {$[32,57,85]$} & {$[32,57,86]$} & {$[32,57,87]$} \\
\hline
\end{tabular}


distant recurrence and overall survival between $\mathrm{BCT}$ and mastectomy in BRCA mutation carriers were reported. To date, no randomized controlled trials of BCT with radiation therapy for breast cancer with $B R C A$ mutations are available. The available information is drawn from retrospective studies, case reports, or reviews.

Because of the risk of developing new cancers in the long term, mastectomy is not recommended unless $B R C A$ alterations are detected preoperatively or in case the patient strongly desires breast-conserving surgery.

\section{Systematic therapy}

Abnormality in the BRCA gene impairs the DNA repair pathway, resulting in the accumulation of damaged DNA. Reportedly, patients with $B R C A$ mutations are highly sensitive to drugs that cause DNA damage, such as platinum doublet and PARP (poly (ADP-ribose) polymerase) inhibitors.

\section{Platinum doublet}

In a Phase III TNT study, to compare the effectiveness of carboplatin and docetaxel in TNBC or germline BRCAl/2 mutation-positive breast cancer with metastatic recurrence, both overall response rate (ORR) and progressionfree survival (PFS) were significantly improved in the carboplatin-treated group (ORR: $68 \%$ vs. $33.3 \%$, median PFS: 6.8 months vs. 4.4 months). However, no difference was observed in overall survival (OS) [90]. On the other hand, in neoadjuvant chemotherapy, the subgroup analysis of TNBC in the GeparSixto study showed that even if paclitaxel, non-pegylated liposomal doxorubicin, and bevacizumab were combined with carboplatin among germline $B R C A$ mutation-positive patients, the $\mathrm{pCR}$ rate did not change. It has been suggested that the effect of carboplatin may not have been observed due to the DNA repair fraud effect of doxorubicin [91].

\section{PARP inhibitor}

Tumors with HRR abnormalities, such as BRCA-mutant cancers, are known to be sensitive to platinum products that cause interstrand cross-linking (ICL). Although various drugs have been developed, the search for biomarkers that can predict their effectiveness is underway. PARP is an enzyme that participates in the repair of single-strand breaks in DNA via the BER pathway. If DNA single-strand break repair is impaired, the single-strand break is converted to a double-strand break and repaired via the double-strand break repair machinery. However, in cells with impaired HRR function, such as BRCA-mutant cancer, repair via non-homologous end joining (NHEJ) or microhomologymediated end joining (MMEJ), may occur. NHEJ and MMEJ are highly error-prone repair mechanisms, and cells repaired via these mechanisms undergo complex genomic rearrangements and cell death. This series of events is called synthetic lethality [92]. Two Phase III studies tested PARP inhibitors for metastatic recurrent HER2-negative germline BRCA-positive breast cancer, OlympiAD, comparing Olaparib alone with standard physicians' choice of chemotherapy, showed a significant prolongation of PFS with a median of 7.0 months versus 4.2 months [93]; another trial, EMBRACA, compared talazoparib monotherapy with standard physicians' choice of chemotherapy, and also showed significantly prolonged PFS with a median of 8.6 months versus 5.6 months [94]. These two drugs are drugs approved in many countries, including by the FDA. At present, clinical trials with germline $B R C A$ mutation-positive patients using PARP inhibitors and other agents, including platinum doublet, ATR inhibitors, anti PD-L1, etc., are in progress. On the other hand, a Phase III study (OlympiA study) is underway to verify the usefulness of additional Olaparib in patients with high-risk recurrence who are germline $B R C A$ mutation-positive after neoadjuvant or adjuvant chemotherapy.

Reportedly, PARP inhibitors may be effective for tumors that share features of BRCA-mutant tumors-that is, those with 'BRCAness' [95], including BRCA cancers. At present, various tools for predicting HRD have been developed, but

Table 5 Current HRR assays

\begin{tabular}{|c|c|c|c|}
\hline & BRCAness $®$ & myChoice ${ }^{\circledR}$ HRD & HRDetect \\
\hline Sample & FFPE & FFPE & $\mathrm{FF}$ \\
\hline Method & $\begin{array}{l}\text { Tumor samples were measured using } \\
\text { the MLPA method for } 34 \text { copy number } \\
\text { abnormalities that were significantly } \\
\text { observed in gBRCAl-positive tumors, } \\
\text { and scored using PAM statistics }\end{array}$ & $\begin{array}{l}\text { Analysis of BRCA1 / } 2 \text { tumor samples and } \\
\text { analysis of genomic instability (HRD } \\
\text { score) }\end{array}$ & $\begin{array}{l}\text { Perform WGS on tumor samples and } \\
\text { calculate } 6 \text { parameters of signature }(3 \text {, } \\
\text { 8), rearrangement signature }(3,5) \text {, dele- } \\
\text { tions with MH, and HRD using logistic } \\
\text { regression analysis }\end{array}$ \\
\hline Purpose & Decision on the treatment plan for TNBC & PARP inhibitor effect prediction & $\begin{array}{l}\text { Measures loss of } B R C A 1 / 2 \text { function in } \\
\text { tumor }\end{array}$ \\
\hline References & Lips [96] & Timms [97] & Davies [98] \\
\hline
\end{tabular}


it is unclear which HRR assay has the highest sensitivity for predicting the effect of a drug. The results of clinical trials are awaited (Table 5) [96-98].

\section{Cancer prevention}

Knowledge regarding one's predisposition to germline cancer enables the adoption of appropriate measures. Cancer prevention includes risk-reducing surgery and chemoprevention. Preventive care should be decided upon consultation with genetic counseling if desired. Currently, among the genes related to hereditary breast cancer, only BRCAI/2 genes can be considered to have evidence of the medical utility of preventive care.

\section{Risk-reducing surgery}

\section{Risk-reducing mastectomy (RRM)}

Contralateral breast risk-reduction resection can be performed after the onset of unilateral breast cancer, and bilateral breast risk-reduction resection can be performed for those without breast cancer. Recently, meta-analyses of breast cancer risk and mortality after bilateral and contralateral prophylactic mastectomy have been reported. In total, there are 2,555 cases for bilateral breast risk-reduction resection and 1,672 cases for contralateral resection. Breast cancer-specific risk after prophylactic mastectomy was significantly reduced to relative risk $=0.11$ and 0.072 for bilateral and contralateral resections, respectively. Overall mortality did not differ significantly after bilateral prophylactic mastectomy but was significant after contralateral prophylactic mastectomy. Breast cancer-specific mortality did not differ significantly after bilateral (hazard ratio $=0.226$ ) and contralateral (hazard ratio $=0.512$ ) prophylactic mastectomy. However, in one of the studies, breast cancer-specific mortality after contralateral prophylactic mastectomy showed a significant difference when analyzed after extending the follow-up period from 10 to 20 years (hazard ratio $=0.52$ ) [99].

\section{Risk-reducing salpingo-oophorectomy (RRSO)}

RRSO has been used successfully. A meta-analysis of 2,871 cases in three studies showed a significant reduction in the risk of ovarian cancer, with a hazard ratio of 0.21 [100], and a meta-analysis of three other prospective studies involving 9192 cases showed a decrease in overall mortality with a hazard ratio of 0.32 . Overall mortality was significantly reduced in both subgroup analyses for patients with a history of BRCA1- and BRCA2-mutated breast cancer and no history of breast cancer. In addition, incidences of RRSO and breast cancer in women lacking BRCAl/2 mutation have been reported [101]. Analysis of all BRCA1/2 cases showed no reduction in the risk of developing breast cancer in the RRSO-treated group, although the BRCA2 mutation-bearing group showed an $83 \%$ reduction in risk at $<50$ years of age. RRSO was similarly effective in preventing breast cancer (hazard ratio $=0.10, p=0.03$ ) for women under 50 years of age who could be persuaded for analyzing their estrogen receptor positivity. $B R C A l$ has a large risk-reduction effect on ovarian cancer, whereas $B R C A 2$ has a risk-reduction effect on breast cancer after RRSO. Thus, RRSO should be performed based on the above information. We expect that in future genetic counseling will offer more reliable predictions of the quality of life for patients carrying $B R C A 1 / 2$ mutations.

\section{Conclusion}

Many hereditary tumors, including hereditary breast cancers, are syndromes characterized by the development of different types of cancer in succession. Taking advantage of knowing the predisposition of susceptibility to cancer, it is vital to continue management, which includes the adoption of preventive measures, countermeasures, and treatments, and assessment of the impact on the next generation of patients.

Acknowledgements The author thanks Seigo Nakamura Division of Breast Surgical Oncology, Department of Surgery, and the Showa University School of Medicine.

\section{Compliance with ethical standards}

Conflict of interest The author declares no relevant conflict of interest with respect to the contents of this manuscript.

Open Access This article is licensed under a Creative Commons Attribution 4.0 International License, which permits use, sharing, adaptation, distribution and reproduction in any medium or format, as long as you give appropriate credit to the original author(s) and the source, provide a link to the Creative Commons licence, and indicate if changes were made. The images or other third party material in this article are included in the article's Creative Commons licence, unless indicated otherwise in a credit line to the material. If material is not included in the article's Creative Commons licence and your intended use is not permitted by statutory regulation or exceeds the permitted use, you will need to obtain permission directly from the copyright holder. To view a copy of this licence, visit http://creativecommons.org/licenses/by/4.0/.

\section{References}

1. https://gco.iarc.fr/. Accessed 7 Sept 2020

2. Ford D, Easton DF, Bishop DT, Narod SA, Goldgar DE. Risks of cancer in BRCA1-mutation carriers. Breast Cancer Linkage Consortium. Lancet. 1994;343:692-5. 
3. National Cancer Institute Dictionary of Cancer Terms https ://www.cancer.gov/publications/dictionaries/cancer-terms. Accessed 7 Sept 2020

4. Hall JM, Lee MK, Newman B, Morrow JE, Anderson LA, Huey $\mathrm{B}$, et al. Linkage of early-onset familial breast cancer to chromosome 17q21. Science. 1990;250:1684-9.

5. Miki Y, Swensen J, Shattuck-Eidens D, Futreal PA, Harshman K, Tavtigian S, et al. A strong candidate for the breast and ovarian cancer susceptibility gene BRCA1. Science. 1994;266:66-71.

6. Hashizume R, Fukuda M, Maeda I, Nishikawa H, Oyake D, Yabuki Y, et al. The RING heterodimer BRCA1-BARD1 is a ubiquitin ligase inactivated by a breast cancer-derived mutation. J Biol Chem. 2001;276:14537-40.

7. Yu X, Chini CC, He M, Mer G, Chen J. The BRCT domain is a phospho-protein binding domain. Science. 2003;302:639-42.

8. Manke IA, Lowery DM, Nguyen A, Yaffe MB. BRCT repeats as phosphopeptide-binding modules involved in protein targeting. Science. 2003;302:636-9.

9. Wang B, Matsuoka S, Ballif BA, Zhang D, Smogorzewska A, Gygi SP, et al. Abraxas and RAP80 form a BRCA1 protein complex required for the DNA damage response. Science. 2007;316:1194-8.

10. Zhang F, Ma J, Wu J, Ye L, Cai H, Xia B, et al. PALB2 links BRCA1 and BRCA2 in the DNA-damage response. Curr Biol. 2009;19:524-9.

11. Wooster R, Bignell G, Lancaster J, Swift S, Seal S, Mangion $\mathrm{J}$, et al. Identification of the breast cancer susceptibility gene BRCA2. Nature. 1995;378:789-92.

12. Chatterjee G, Jimenez-Sainz J, Presti T, Nguyen T, Jensen RB. Distinct binding of BRCA2 BRC repeats to RAD51 generates differential DNA damage sensitivity. Nucleic Acids Res. 2016;44:5256-70.

13. Yang H, Li Q, Fan J, Holloman WK, Pavletich NP. BRCA2 homologue Brh2 nucleates RAD51 filament formation at a dsDNAssDNA junction. Nature. 2005;433:653-7.

14. Lord CJ, Ashworth A. The DNA damage response and cancer therapy. Nature. 2012;481:287-94.

15. Venkitaraman AR. Cancer suppression by the chromosome custodians, BRCA1 and BRCA2. Science. 2014;343:1470-5.

16. Sasanuma H, Tsuda M, Morimoto S, Saha LK, Rahman MM, Kiyooka Y, et al. BRCA1 ensures genome integrity by eliminating estrogen-induced pathological topoisomerase II-DNA complexes. Proc Natl Acad Sci USA. 2018;115:E10642-E1065110651.

17. Liu S, Ginestier C, Charafe-Jauffret E, Foco H, Kleer CG, Merajver SD, et al. BRCA1 regulates human mammary stem/progenitor cell fate. Proc Natl Acad Sci USA. 2008;105:1680-5.

18. Kais Z, Parvin JD. Regulation of centrosomes by the BRCA1dependent ubiquitin ligase. Cancer Biol Ther. 2008;7:1540-3.

19. Clarke PR, Sanderson HS. A mitotic role for BRCA1/BARD1 in tumor suppression? Cell. 2006;127:453-5.

20. Zhu Q, Pao GM, Huynh AM, Suh H, Tonnu N, Nederlof PM, et al. BRCA1 tumour suppression occurs via heterochromatinmediated silencing. Nature. 2011;477:179-84.

21. Gorski JJ, Kennedy RD, Hosey AM, Harkin DP. The complex relationship between BRCA1 and ERalpha in hereditary breast cancer. Clin Cancer Res. 2009;5:1514-8.

22. Savage KL, Gorski JJ, Barrons EM, Irwin GW, Manti L, Powell $\mathrm{AJ}$, et al. Identification of a BRCA1-mRNA splicing complex required for efficient DNA repair and maintenance of genomic stability. Mol Cell. 2014;54:445-59.

23. Pao GM, Zhu Q, Perez-Garcia CG, Chou SJ, Suh H, Gage FH, et al. Role of BRCA1 in brain development. Proc Natl Acad Sci USA. 2014;111:1240-8.

24. Savage KL, Harkin DP. BRCA1, a 'complex' protein involved in the maintenance of genomic stability. FEBS J. 2015;282:630-46.
25. ClinVar: https://www.ncbi.nlm.nih.gov/clinvar. Accessed 7 Sept 2020

26. Anczuków O, Ware MD, Buisson M, Zetoune AB, StoppaLyonnet D, Sinilnikova OM, et al. Does the nonsense-mediated mRNA decay mechanism prevent the synthesis of truncated BRCA1, CHK2, and p53 proteins? Hum Mutat. 2008;29:65-73.

27. Venkitaraman AR. How do mutations affecting the breast cancer genes BRCA1 and BRCA2 cause cancer susceptibility? DNA Repair (Amst). 2019;81:102668.

28. Palma MD, Domchek SM, Stopfer J, Erlichman J, Siegfried JD, Tigges-Cardwell J, et al. The relative contribution of point mutations and genomic rearrangements in BRCA1 and BRCA2 in high-risk breast cancer families. Cancer Res. 2008;68:7006-144.

29. Ewald IP, Ribeiro PL, Palmero EI, Cossio SL, Giugliani R, Ashton-Prolla P. Genomic rearrangements in BRCA1 and BRCA2: A literature review. Genet Mol Biol. 2009;32:437-46.

30. Kang P, Mariapun S, Phuah SY, Lim LS, Liu J, Yoon SY, et al. Large BRCA1 and BRCA2 genomic rearrangements in Malaysian high risk breast-ovarian cancer families. Breast Cancer Res Treat. 2010;124:579-84.

31. Judkins T, Rosenthal E, Arnell C, Burbidge LA, Geary W, Barrus $\mathrm{T}$, et al. Clinical significance of large rearrangements in BRCA1 and BRCA2. Cancer. 2012;118:5210-6.

32. GeneReview: https://www.ncbi.nlm.nih.gov/books/NBK1247/. Accessed 7 Sept 2020

33. Phelan CM, Kwan E, Jack E, Li S, Morgan C, Aube J, et al. A low frequency of non-founder BRCA1 mutations in Ashkenazi Jewish breast-ovarian cancer families. Hum Mutat. 2002;20:352-7.

34. Frank TS, Deffenbaugh AM, Reid JE, Hulick M, Ward BE, Lingenfelter B, Gumpper KL, et al. Clinical characteristics of individuals with germline mutations in BRCA1 and BRCA2: analysis of 10,000 individuals. J Clin Oncol. 2002;20:1480-90.

35. Ramus SJ, Gayther SA. The contribution of BRCA1 and BRCA2 to ovarian cancer. Mol Oncol. 2009;3:138-50.

36. Ferla R, Calò V, Cascio S, Rinaldi G, Badalamenti G, Carreca I, et al. Founder mutations in BRCA1 and BRCA2 genes. Ann Oncol. 2007;18(6):93-8.

37. Kwong A, Ng EK, Wong CL, Law FB, Au T, Wong HN, et al. Identification of BRCA1/2 founder mutations in Southern Chinese breast cancer patients using gene sequencing and high resolution DNA melting analysis. PLoS ONE. 2012;7:e43994.

38. Kim YC, Zhao L, Zhang H, Huang Y, Cui J, Xiao F, et al. Prevalence and spectrum of BRCA germline variants in mainland Chinese familial breast and ovarian cancer patients. Oncotarget. 2016;7:9600-12.

39. Yoshida R, Watanabe C, Yokoyama S, Inuzuka M, Yotsumoto J, Arai M, et al. Analysis of clinical characteristics of breast cancer patients with the Japanese founder mutation BRCA1 L63X. Oncotarget. 2019;10:3276-84.

40. Sekine M, Nagata H, Tsuji S, Hirai Y, Fujimoto S, Hatae M, et al. Mutational analysis of $B R C A 1$ and $B R C A 2$ and clinicopathologic analysis of ovarian cancer in 82 ovarian cancer families: two common founder mutations of BRCA1 in Japanese population. Clin Cancer Res. 2001;7:3144-50.

41. Kang E, Kim SW. The Korean hereditary breast cancer study: review and future perspective. J Breast Cancer. 2013;16:245-53.

42. Kang E, Seong MW, Park SK, Lee JW, Lee J, Kim LS, et al. The prevalence and spectrum of BRCA1 and BRCA2 mutations in Korean population: recent update of the Korean hereditary breast cancer (KOHBRA) study. Breast Cancer Res Treat. 2015;151:157-68.

43. Choi MC, Heo J-H, Jang J-H, Jung SG, Park H, Joo WD, et al. Germline mutations of $B R C A 1$ and $B R C A 2$ in Korean ovarian cancer patients. Int J Gynecol Cancer. 2015;25:1386-91. 
44. Lee ASG, Ho GH, Oh PC, Balram C, Ooi LL, Lim DTH, et al. Founder mutation in the BRCA1 gene in Malay breast cancer patients from Singapore. Hum Mutat. 2003;22:178.

45. De Leon Matsuda ML, Liede A, Kwan E, Mapua CA, Cutiongco EMC, Tan A, et al. BRCA1 and BRCA2 mutations among breast cancer patients from the Philippines. Int J Cancer. 2002;98:596-603.

46. Anglian Breast Cancer Study Group. Prevalence and penetrance of BRCA1 and BRCA2 mutations in a population-based series ofbreast cancer cases. Br J Cancer. 2000;83:1301-8.

47. Whittemore AS, Gong G, John EM, McGuire V, Li FP, Ostrow KL, et al. Prevalence of BRCA1 mutation carriers among U.S. non-Hispanic Whites. Cancer Epidemiol Biomarkers Prev. 2004;13:2078-83.

48. King MC, Marks JH, Mandell JB, New York Breast Cancer Study Group. Breast and ovarian cancer risks due to inherited mutations in BRCA1 and BRCA2. Science. 2003;302:643-6.

49. Momozawa Y, Iwasaki Y, Parsons MT, Kamatani Y, Takahashi A, Tamura C, et al. Germline pathogenic variants of 11 breast cancer genes in 7,051 Japanese patients and 11,241 controls. Nat Commun. 2018;9:4083.

50. Sun J, Meng H, Yao L, Lv M, Bai J, Zhang J, et al. Germline mutations in cancer susceptibility genes in a large series of unselected breast cancer patients. Clin Cancer Res. 2017;23:6113-9.

51. Wen WX, Allen J, Lai KN, Mariapun S, Hasan SN, Ng PS, et al. Inherited mutations in BRCA1 and BRCA2 in an unselected multiethnic cohort of Asian patients with breast cancer and healthy controls from Malaysia. J Med Genet. 2018;55:97-103.

52. Tung N, Lin NU, Kidd J, Allen BA, Singh N, Wenstrup RJ, et al. Frequency of germline mutations in 25 cancer susceptibility genes in a sequential series of patients with breast cancer. J Clin Oncol. 2016;34:1460-8.

53. Song H, Cicek MS, Dicks E, Harrington P, Ramus SJ, Cunningham JM, et al. The contribution of deleterious germline mutations in BRCA1, BRCA2 and the mismatch repair genes to ovarian cancer in the population. Hum Mol Genet. 4703e;23:4703e9.

54. Alsop K, Fereday S, Meldrum C, deFazio A, Emmanuel C, George J, et al. BRCA mutation frequency and patterns of treatment response in BRCA mutation-positive women with ovarian cancer: a report from the Australian Ovarian Cancer Study Group. J Clin Oncol. 2654e;30:2654e63.

55. Zhang S, Royer R, Li S, McLaughlin JR, Rosen B, Risch HA, et al. Frequencies of $B R C A 1$ and $B R C A 2$ mutations among 1,342 unselected patients with invasive ovarian cancer. Gynecol Oncol. 2011;121:353e7.

56. Enomoto T, Aoki D, Hattori K, Jinushi M, Kigawa J, Takeshima N, et al. The first Japanese nationwide multicenter study of BRCA mutation testing in ovarian cancer: characterizing the cross-sectional approach to ovarian cancer genetic testing of BRCA (CHARLOTTE). Int J Gynecol Cancer. 2019;29:1043-9.

57. NCCN Clinical Practice Guidelines in Oncology (NCCN Guidelines) Genetic/Familial High-Risk Assessment: Breast, Ovarian, and Pancreatic Version 1.2020

58. Parmigiani G, Berry D, Aguilar O. Determining carrier probabilities for breast cancer-susceptibility genes BRCA1 and BRCA2. Am J Hum Genet. 1998;62:145-58.

59. Antoniou AC, Pharoah PP, Smith P, Easton DF. The BOADICEA model of genetic susceptibility to breast and ovarian cancer. Br J Cancer. 2004;91:1580-90.

60. Tyrer J, Duffy SW, Cuzick J. A breast cancer prediction model incorporating familial and personal risk factors. Stat Med. 2004;23:1111-30.

61. Kang E, Park SK, Lee JW, Kim Z, Noh WC, Jung Y, et al. KOHBRA BRCA risk calculator ( $\mathrm{KOHCal})$ : a model for predicting
$B R C A 1$ and $B R C A 2$ mutations in Korean breast cancer patients. J Hum Genet. 2016;61:365-71.

62. Antoniou A, Pharoah PD, Narod S, Risch HA, Eyfjord JE, Hopper JL, et al. Average risks of breast and ovarian cancer associated with $B R C A 1$ or $B R C A 2$ mutations detected in case series unselected for family history: a combined analysis of 22 studies. Am J Hum Genet. 2003;72:1117-30.

63. Chen S, Parmigiani G. Meta-analysis of BRCA1 and BRCA2 penetrance. J Clin Oncol. 2007;10(25):1329-33.

64. Kuchenbaecker KB, Hopper JL, Barnes DR, Phillips K-A, Mooij $\mathrm{TM}$, Roos-Blom MJ, et al. Risks of breast, ovarian, and contralateral breast cancer for $B R C A 1$ and $B R C A 2$ mutation carriers. JAMA. 2017;317:2402-16.

65. Valachis A, Nearchou AD, Lind P. Surgical management of breast cancer in BRCA-mutation carriers: a systematic review and meta-analysis. Breast Cancer Res Treat. 2014;144:443-55.

66. Gao X, Fisher SG, Emami B. Risk of second primary cancer in the contralateral breast in women treated for early-stage breast cancer: a population-based study. Int J Radiat Oncol Biol Phys. 2003;56:1038-45.

67. Metcalfe K, Gershman S, Lynch HT, Ghadirian P, Tung N, KimSing $\mathrm{C}$, et al. Predictors of contralateral breast cancer in BRCA1 and BRCA2 mutation carriers. Br J Cancer. 2011;104:1384-92.

68. Rebbeck TR, Mitra N, Wan F, Sinilnikova OM, Healey S, McGuffog L, et al. Association of type and location of BRCAI and $B R C A 2$ mutations with risk of breast and ovarian cancer. JAMA. 2015;313:1347-61.

69. Pijpe A, Andrieu N, Easton DF, Kesminiene A, Cardis E, Nogues $\mathrm{C}$, et al. Exposure to diagnostic radiation and risk of breast cancer among carriers of BRCA1/2 mutations: retrospective cohort study (GENE-RAD-RISK). Br Med J. 2012;345:e5660.

70. Giannakeas V, Lubinski L, Gronwald J, Moller P, Armel S, Lynch HT, et al. Mammography screening and the risk of breast cancer in BRCA1 and BRCA2 mutation carriers: a prospective study. Br Cancer Res Treat. 2014;147:13-8.

71. Mavaddat N, Barrowdale D, Andrulis IL, Domchek SM, Eccles $\mathrm{D}$, Nevanlinna H, et al. Pathology of breast and ovarian cancers among BRCA1 and BRCA2 mutation carriers: results from the Consortium of Investigators of Modifiers of BRCA1/2 (CIMBA). Cancer Epidemiol Biomarkers Prev. 2012;21:134-47.

72. Kuchenbaecker KB, Neuhausen SL, Robson M, Barrowdale D, McGuffog L, Mulligan AM, et al. Associations of common breast cancer susceptibility alleles with risk of breast cancer subtypes in BRCA1 and BRCA2 mutation carriers. Breast Cancer Res. 2014;16:3416.

73. McLaughlin JR, Rosen B, Moody J, Pal T, Fan I, Shaw PA, et al. Long-term ovarian cancer survival associated with mutation in BRCA1 or BRCA2. J Natl Cancer Inst. 2013;105:141-9.

74. Templeton AJ, Gonzalez LD, Vera-Badillo FE, Tibau A, Goldstein $\mathrm{R}$, Šeruga B, et al. Interaction between hormonal receptor status, age and survival in patients with $B R C A 1 / 2$ germline mutations: a systematic review and meta-regression. PLoS ONE. 2016;11:e0154789.

75. Copson ER, Maishman TC, Tapper WJ, Cutress RI, GrevilleHeygate S, Altman DG, et al. Germline BRCA mutation and outcome in young-onset breast cancer (POSH): a prospective cohort study. Lancet Oncol. 2018;19:169-80.

76. Maxwell KN, Wubbenhorst B, Wenz BM, De Sloover D, Pluta $\mathrm{J}$, Emery L, et al. BRCA locus-specific loss of heterozygosity in germline BRCA1 and BRCA2 carriers. Nat Commun. 2017;8:319.

77. Melchor L, Benitez J. The complex genetic landscape of familial breast cancer. Hum Genet. 2013;132:845-63.

78. Nielsen FC, van Overeem HT, Sørensen CS. Hereditary breast and ovarian cancer: new genes in confined pathways. Nat Rev Cancer. 2016;16:599. 
79. Buys SS, Sandbach JF, Gammon A, Patel G, Kidd J, Brown KL, et al. A study of over 35,000 women with breast cancer tested with a 25 -gene panel of hereditary cancer genes. Cancer. 2017;123:1721-30.

80. Couch FJ, Shimelis H, Hu C, Hart SN, Polley EC, Na J, et al. Associations between cancer predisposition testing panel genes and breast cancer. JAMA Oncol. 2017;3:1190-6.

81. Theobald KA, Susswein LR, Marshall ML, Roberts ME, Mester JL, Speyer D, et al. Utility of expedited hereditary cancer testing in the surgical management of patients with a new breast cancer diagnosis. Ann Surg Oncol. 2018;25:3556-622.

82. Catana A, Apostu AP, Antemie R-G. Multi gene panel testing for hereditary breast cancer-is it ready to be used? Med Pharm Rep. 2019;92:220-5.

83. Melhem-Bertrandt A, Bojadzieva J, Ready KJ, Obeid E, Liu DD, Gutierrez-Barrera AM, et al. Onset HER2-positive breast cancer is associated with germline TP53 mutations. Cancer. 2012;118:908-13.

84. Rath MG, Masciari S, Gelman R, Miron A, Miron P, Foley K, et al. Prevalence of germline TP53 mutations in HER2-positive breast cancer patients. Breast Cancer Res Treat. 2013;139:193-8.

85. Ngeow J, Sesock K, Eng C. Breast cancer risk and clinical implications for germline PTEN mutation carriers. Breast Cancer Res Treat. 2017;165:1-8.

86. Figueiredo J, Melo S, Carneiro P, Moreira AM, Fernandes MS, Ribeiro AS, et al. Clinical spectrum and pleiotropic nature of CDH1 germline mutations. J Med Genet. 2019;56:199-208.

87. Meserve EE, Nucci MR. Peutz-Jeghers syndrome: pathobiology, pathologic manifestations, and suggestions for recommending genetic testing in pathology reports. Surg Pathol Clin. 2016;9:243-68.

88. NCCN Clinical Practice Guidelines in Oncology (NCCN Guidelines) Breast Cacner Version 3.2020

89. Vallard A, Magne N, Guy J-B, Espenel S, Chloe R, Diao P, et al. Is breast-conserving therapy adequate in $B R C A 1 / 2$ mutation carriers? The radiation oncologist's point of view. Br J Radio. 2019;92:20170657.

90. Tutt A, Tovey H, Cheang MCU, Kernaghan S, Kilburn L, Gazinska P, et al. Carboplatin in BRCA1/2-mutated and triple-negative breast cancer BRCAness subgroups: the TNT Trial. Nat Med. 2018;24(5):628-37.

91. Hahnen E, Lederer B, Hauke J, Loibl S, Kröber S, Schneeweiss A, et al. Germline mutation status, pathological complete response, and disease-free survival in triple-negative breast cancer: secondary analysis of the GeparSixto randomized clinical trial. JAMA Oncol. 2017;3(10):1378-85.

92. Konecny GE, Kristeleit RS. PARP Inhibitors for BRCA1/2mutated and Sporadic Ovarian Cancer: Current Practice and Future Directions. Br J Cancer. 2016;115:1157-73.

93. Robson M, Im S-A, Senkus E, Xu B, Domchek SM, Masuda $\mathrm{N}$, et al. Olaparib for metastatic breast cancer in patients with a germline BRCA mutation. N Engl J Med. 2017;377:523-33.

94. Litton JK, Rugo HS, Ettl J, Hurvitz SA, Gonçalves A, Lee KH, et al. Talazoparib in patients with advanced breast cancer and a germline BRCA mutation. N Engl J Med. 2018;379:753-63.

95. Lord CJ, Ashworth A. BRCAness revisited. Nat Rev Cancer. 2016;16(2): 110 .

96. Lips EH, Laddach N, Savola SP, Vollebergh MA, Oonk AM, Imholz AL, et al. Quantitative copy number analysis by multiplex ligation-dependent probe amplification (MLPA) of BRCA1-associated breast cancer regions identifies BRCAness. Breast Cancer Res. 2011;13:R107.

97. Timms KM, Abkevich V, Hughes E, Neff C, Reid J, Morris B, et al. Association of $B R C A 1 / 2$ defects with genomic scores predictive of DNA damage repair deficiency among breast cancer subtypes. Breast Cancer Res. 2014;16:475.

98. Davies H, Glodzik D, Morganella S, Yates LR, Staaf J, Zou X, et al. HRDetect is a predictor of BRCA1 and BRCA2 deficiency based on mutational signatures. Nat Med. 2017;23:517.

99. Li X, You R, Wang X, Liu C, Xu Z, Zhou J, et al. Effectiveness of prophylactic surgeries in $B R C A 1$ or $B R C A 2$ mutation carriers: a meta-analysis and systematic review. Clin Cancer Res. 2016;22:3971-81.

100. Rebbeck TR, Kauff ND, Domchek SM. Meta-analysis of risk reduction estimates associated with risk-reducing salpingooophorectomy in BRCA1 or BRCA2 mutation carriers. J Natl Cancer Inst. 2009;101:80-7.

101. Kotsopoulos J, Huzarski T, Gronwald J, Singer CF, Moller P, Lynch HT, et al. Bilateral oophorectomy and breast cancer risk in BRCA1 and BRCA2 mutation carriers. J Natl Cancer Inst. 2017. https://doi.org/10.1093/jnci/djx038.

Publisher's Note Springer Nature remains neutral with regard to jurisdictional claims in published maps and institutional affiliations. 